Janis Rozenfelds, Ph.D., Professor

University of Latvia, Latvia

\title{
PROPERTY RIGHTS APPLICABLE TO IMMOVABLE PROPERTY
}

\begin{abstract}
Summary
The amendment to Section 19 of the law "On Recording of Immovable Property in the Land Registers" was passed in 1997. This proposal by the Ministry of Justice was advanced without any explanation, and it can be easily reversed. The littoral zone shall belong to the State. However, it should be added that this right must be established as the public domain and for the public use.
\end{abstract}

Keywords: pipelines, littoral zone, obligations, right of superficies, adverse possession, registration, Land Register

\section{Introduction}

Latvian Civil Law ${ }^{1}$ does not provide a clear definition of immovable property. It could be either a land plot or a building apart from land $\mathrm{d}^{2}$, and not all of these may be registered as immovable property. Such uncertainty increases probability of litigations which otherwise would be unnecessary.

The littoral zone (in some normative acts named also costal line - see below) shall belong to the State to that point which the highest breakers of the sea reach (Section 1104 of CL). Conception on recording of the costal line of the Baltic Sea and the Gulf of Riga in the name of the State, approved by the Cabinet ${ }^{3}$ is one step back from the principle that littoral zone should be exclusively state owned. This approach created a possibility that a part of the state property could be turned into

1 The Civil Law (civil code) which was entered into force in 1937, then suspended in 1940 and gradually re-entered again in 1992-1993, hereafter referred to as CL.

2 Rozenfelds J. Entropy of Physical Unity of property (ad caelum) in the Latvian Law. International Scientific Conference "The Quality of Legal Acts and its Importance in Contemporary Legal Space”. 4-5 October, 2012 at the University of Latvia, Faculty of Law, Riga, 2012, pp. 615-625; Rozenfelds J. Superficies solo cedit in the Latvian Law. Journal of the University of Latvia No. 5. Law, 2013. J. Lazdinš (ed.-in-chief), Riga: University of Latvia, 2013, pp. 120-136; Rozenfelds J. Reform of Land Registration in Latvia. Juridica International Law Review. University of Tartu: Estonia, 22/2014, pp. 43-50.

3 Par Koncepciju par Baltijas jūras un Riggas jūras līča piekrastes joslas ierakstǐšanu zemesgrāmatā uz valsts vārda. Ministru kabineta rīkojums Nr. 241 Rỉgā, 2008. gada 29. aprīī (prot. Nr. 27 24.\$) [Regarding Conception on recording of the costal line of the Baltic Sea and the Gulf of Riga in the name of the State. Cabinet Regulation No. 241]. Available at: https://likumi.lv/ta/id/174726par-koncepciju-par-baltijas-juras-un-rigas-juras-lica-piekrastes-joslas-ierakstisanu-zemesgramata-uzvalsts-varda [last viewed September 4, 2019]. 
the private one. This in turn could have impact upon the rights of private individuals to enjoy free use of the littoral zone.

Right of superficies ${ }^{4}$ as an exclusion from general superficies solo cedit 5 principle was included in the CL only in $2017^{6}$ in order to get rid of divided property. However, these amendments are too narrow. They cannot provide solution for the problem of divided or split property rights.

Registration of obligations in the Land Register is an exception to the general principle that only rights in rem can be registered in the Land Register. Registration of rights in personam is an exception to the rule. There should be an exhaustive list of rights subject to such registration (so-called numerus clausus). Our case law has interpreted the above principles differently. The recent practice in dealing with acquisition of immovable property through adverse possession appears to be in conflict with the principle of public reliability of the Land Register.

\section{Pipelines and subterranean structures}

Surface and underground utilities, pipeline routes, roads, streets, parking lots and other similar buildings shall not be recorded in the Land Register as independent objects of property (Section 19 of Law on Recording of Immovable Property in the Land Registers).

This exception has caused numerous disputes as to who owns what. In one of the court disputes over some 110 thousand metric tons of oil between a Belorussian and a Latvian company, ${ }^{7}$ the latter claimed the ownership of oil on the basis of owning the pipeline, and claiming that the oil should be regarded as appurtenance to the said pipeline. However, the pipeline in dispute, which is crossing almost

\footnotetext{
Superficies - the right of superficiarius, i.e., a person other than the owner of the land, to use, pledge and dispose in any other way the improvement (building, utility etc.) that stands on the surface of the ground. See also Black's Law Dictionary $7^{\text {th }}$ edition. Garner B. A. (ed.-in-chief). St. Paul, Minn: West Group, 1999, p. 1451.

5 The rule of superficies solo cedit, i.e., that the ownership of a piece of land generally also comprises the ownership of all the buildings erected on the land, applies in all European legal systems. The generally recognised exceptions are building leases (not recognised in Scotland) and apartment ownership. Further exceptions of separate ownership of buildings exist in the Reform States of Middle and Eastern Europe. Cited from: Real Property Law and Procedure in the European Union. General Report. Final Version. Scientific co-ordinators: Dr. habil. Christoph U. Schmid, Ph.D. European Private Law Forum European University Institute, Florence, www.iue.it; Christian Hertel, LL.M. Director DNotI (German Notary Institute), Würzburg, www.dnoti.de with contributions by Dr. Hartmut Wicke, LL.M., DNotI, Würzburg. 31.5.2005 European University Institute (EUI) Florence/European Private Law Forum Deutsches Notarinstitut (DNotI) Würzburg. p. 14. Available at: https://www.eui.eu/Documents/DepartmentsCentres/Law/ResearchTeaching/ ResearchThemes/EuropeanPrivateLaw/RealPropertyProject/GeneralReport.pdf [last viewed September 9, 2019].

6 Amendments to the Civil Law. Official Publications No. 2015/56.5. Available at: https://www. vestnesis.lv/op/2015/56.5 [last viewed September 3, 2019].

7 Judgement of the Supreme Court Civil law department in the case No. C12307410; SKC-0268/2016 Available at: https://manas.tiesas.lv/eTiesasMvc/nolemumi [last viewed September 3, 2019].
} 
the entire territory of Latvia is not yet registered in the Land Register. Technically, it belongs to numerous owners of land plots, as the said pipeline is firmly attached to the ground following superficies solo cedit principle (Section 968 of CL).

As superficies solo cedit is not closely followed in Latvian law, one can find all kinds of solutions in the Land Register. Some pipelines are registered as a separate property, while the owners of the said pipelines are paying so-called compulsory rent to the land owners. ${ }^{8}$

Pipelines which are not registered in the Land Register apart from land should be regarded either as a part of land (Section 968 of CL), or they can be regarded as belonging to the same land plot as appurtenances. Appurtenance is described by the CL as auxiliary property (Section 851 of CL).

In the abovementioned court case, over 110 thousand metric tons of oil pipelines were neither regarded as a part of the land, nor appurtenance to the immovable property. The apparent difficulty in defining the nature of this pipeline as the subject of property rights was its enormous size, as well as significance for the national economy.

This case illustrates difficulties challenging the Latvian legislator. The amendment of 1997 to Section 19 of the law "On Recording of Immovable Property in the Land Registers", which expressly excluded pipelines from registration in the Land Register, has caused unnecessary difficulties.

The Inčukalns underground gas storage facility (Paragraph 22 Section 1 of Energy $\mathrm{Law}^{9}$ ) is an underground or aboveground object, which is used for storage of natural gas and which is located in the municipalities of Krimulda, Inčukalns and Sejja, and is used for gas storage and supply. It is currently owned by a company Latvijas Gāze (Latvian Gas). ${ }^{10}$ This example concerns so-called linear buildings such as roads, pipelines, sewage systems etc. ${ }^{11}$ Linear buildings which, due to their huge longitude ${ }^{12}$ or latitude (for instance - Inčukalns underground gas storage facility (Paragraph 22 Section 1 of Energy Law ${ }^{13}$ ) cover a great number of land plots) cause difficulties in defining as to who owns what, i.e., where the interests of numerous land owners could collide with the interests of the owner of the linear building.

Linear buildings are mainly intended for public use. Elements of public domain usually do not cause disputes over ownership. Consequently, registration of linear buildings in the Land Register is not necessary and such registration may be found

8 Case No. C33348615 Available at: https://manas.tiesas.lv/eTiesasMvc/nolemumi [last viewed September 3, 2019].

9 Available at: https://likumi.lv/ta/en/en/id/49833-energy-law [last viewed September 3, 2019].

10 Currently owned by AS “Conexus Baltic Grid” Available at: https://www.conexus.lv/pazemesdabasgazes-kratuve) [last viewed September 3, 2019].

11 Cabinet Regulations No. 48, adopted in Riga, on January 10, 2012 (prot. No. 2.21.\$). Provisions for cadastral measurement of buildings, issued according to Paragraphs 1, 2, 3 and 6 of Section 22 of the National Real Estate Cadastre Law. Available at: https://likumi.lv/doc.php?id=243153 [last viewed September 2, 2019].

12 Judgement of the Supreme Court of the Civil law department in the case No. C12307410; SKC-268/2016 (in Latvian, unpublished).

13 Available at: https://likumi.lv/ta/en/en/id/49833-energy-law [last viewed September 3, 2019]. 
only in exceptional cases. The same, however, cannot be attributed to pipelines, sewage systems and electricity lines, which are often subjects of private property. It would be appropriate, however, to give legal protection for the interests of the persons who are dealing with such kind of objects, utility companies in particular. As an example could serve Article20, paragraph 2, Book 5 of the Civil Code of the Netherlands: "[..] the ownership of a network consisting of one or more cables or pipelines destined for transporting solid, fluid or gaseous substances, energy or information that is or will be laid on or above land of other persons belongs to the person who rightfully laid such network or their assignee." ${ }^{14}$

\section{Littoral zone. Property rights related to the public and private waters}

The littoral zone shall belong to the State to that point which the highest breakers of the sea reach (Section 1104 of CL). Apparently the point where the highest breakers of the sea reach to could be found in different places within different time and weather conditions.

Conception on recording of the costal line of the Baltic Sea and the Gulf of Riga in the name of the State approved by the Cabinet regulations No. $241^{15}$ assumed that littoral zone, which happened to belong to the State, has disappeared completely, whereas the private land continued to belong to the previous owners notwithstanding the fact that it had turned into the sea bed. Such approach, firstly, is at odds with well-established foundations of the acquisition and loos of ownership by accession (Section 960-967 CL, secondly, it leads to abandoning of the rightful ownership of part of land which is held by the state in the interests of the public. Proposals, which were worked out by this Conception which was approved by the Cabinet could have negative impact on the public interest. In order to provide adequate protection of the interests of the society it should be established by the law that sea shore (littoral zone) is the public domain and for the public use.

CL does not regard land, which is covered by water as subject to any ownership. Water is regarded as something which extinguishes property rights by permanently flooding land plots or otherwise - the land which has re-emerged from the water either in the form of a newly formed island or in the form of a previous river bed can be acquired by accession (Sections 1105-1108 of CL). There are, however, cadastral

14 The Civil Code of the Netherlands. Kluwer Law International. Wolters Kluwer. Law \& Business. Hans Warendorf. Richard Thomas. Ian Cury-Summer. Kluwer Law International BV, the Netherlands, 2009.

15 Par Koncepciju par Baltijas jūras un Rīgas jūras līča piekrastes joslas ierakstīšanu zemesgrāmatā uz valsts vārda. Ministru kabineta rīkojums Nr. 241 Rỉgā, 2008. gada 29. aprīlī (prot. Nr. 27 24.\$) [Regarding Conception on recording of the costal line of the Baltic Sea and the Gulf of Riga in the name of the State. Cabinet Regulation No. 241]. Available at: https://likumi.lv/ta/id/174726par-koncepciju-par-baltijas-juras-un-rigas-juras-lica-piekrastes-joslas-ierakstisanu-zemesgramata-uzvalsts-varda [last viewed September 4, 2019]. 
data, which show a bed of a private lake as a private land. ${ }^{16}$ Such practice contradicts the abovementioned principle established by $\mathrm{CL}$, in that the land covered by water is subject to any ownership.

In a recent case reviewed by the Supreme Court, a reversed decision was adopted by a lower court instance. The court of lower instance had awarded entire territory of the lake Rāzna (also known as the Sea of Latgale) to the claimant. Apparently, the court had wrongly perceived one of the documents presented by the claimant to be the proof of ownership title, while in fact this paper only proved the claimant's fishing rights. ${ }^{17}$

The case demonstrates, inter alia, that there is little understanding of principal distinction between private ownership and public domain. Latvian Civil Law does not provide a clear distinction between state-owned property, which does not serve public interests, and it is up to the state to keep such property or to alienate it, whereas the objects which are declared public domain are unalienable. It would be preferable to follow example of other states which declares such state-owned objects unalienable.

Property that forms part of the public domain is inalienable and cannot be an object of rights in favour of third persons (Section 823 Italian Civil Code) ${ }^{18}$.

\section{Right of superficies}

Right of superficies was recommended back in 2008 (Sections $1129^{1}-1129^{9}$ of CL). ${ }^{19}$ Right of superficies enacted as amendments and supplements to the Latvian CL in 2017. This was the purpose of the aforementioned amendments, serving as a gradual replacement of existing situation of dual property (i.e., where a building belongs to the owner other than the owner of the land plot) with the right of superficies, i.e., transferring of property rights of the owner of the building into the right of superficies. ${ }^{20}$

16 No. 88720050031. Available at: https://www.kadastrs.lv/\#result [last viewed September 2, 2019].

17 Judgement of the Supreme Court case No. C03026011, SKC-188/2017 ECLI:LV:AT:2017:1005. C03026011.2.S Available at: http://at.gov.lv/lv/judikatura/judikaturas-nolemumu-arhivs/civillietudepartaments/hronologiska-seciba?year=2017 [last viewed September 2, 2019].

18 The Italian Civil Code And Complementary Legislation. Translated in 1969 by Mario Beltramo, Giovanni E. Longo, John H. Merryman. Supplemented, translated and edited by Mario Beltramo (from 1970 through 1996). Subsequently supplemented, translated and edited by Susanna Beltramo. Book three. Property Rights. (Articles 810-1172). Release 2007-1 Issued April 2007. Oceana, Book Three, Booklet 5, p. 3.

19 Rozenfelds J. Pētijums par Civillikuma Lietu tiesību dạlas (ceturtās, piektās, sestās un septītās nodaļas) modernizācijas nepieciešamību [Research on necessity of modernization of the fourth, fifth, sixth and seventh subchapter of the Third Chapter of Civil Law]. Available in Latvian: https:// www.tm.gov.lv/lv/nozares-politika/petijumi [last viewed September 3, 2019].

20 Bērziņš G. Apbūves tiesība risinās dalītā īpašuma problēmu [Right of superficies will solve the problem of the divided property]. Jurista Vârds, October 3, 2014. Available at: https:// juristavards.lv/zinas/265369-gberzins-bapbuvesb-tiesiba-risinas-dalita-ipasuma-problemu/ [last viewed September 2, 2019]. 
Peculiarity of the right of superficies, as provided by amendments to the CL, which are in force since January 1, 2017 is that specific right to the improvements on the surface of the land, which belongs to another person and which is commonly known as the right of superficiarius (see footnote No. 4 of this article) could arise only from the contract between the land owner and the superficiarius. ${ }^{21}$ The abovementioned supplement to the CL could be applied only to the buildings other than dwellings. Soon it became clear that it was impossible to apply this newly established mechanism to linear buildings.

\section{Obligations}

Discussion over the obligation as a subject for registration in the Land Register has been ongoing since restoration of the CL. This discussion has been over interpretation of certain rights, which should or should not be registered in the Land Register.

Registration of obligations is allowed only in exceptional cases. For instance, upon registering a lease or rental contract in the Land Register, the lessee or a tenant shall acquire property rights, which are valid also with respect to third persons (Section 2126 of CL).

The registration of management agreements of residential houses of joint ownership used to carry more weight than lease or rent agreements. Neither the CL nor any other Latvian law expands much on the issue. Thus, the arguing parties only have general principles at hand in dealing with this massive problem (given that a significant number of such agreements have been already registered in the Land Register).

There have been numerous arguments in favour, as well as against such registration. ${ }^{22}$ This judgement could be regarded as a land mark decision. It was regarded as one which would put an end to the unpredictable case law.

Unfortunately, this decision avoided giving scientific analysis of theoretical arguments, which were put forward in recent publications by several authors against such practice. Not only this decision has avoided examination of all scientific arguments which were in circulation, but it also did not make a clear-cut distinction between the transaction that should be regarded as iusta causa traditionis and the delivery (traditio). This decision opened flood gates of various obligations registered in the Land Register which should not have found their way there.

21 Rozenfelds J. Apbūves tiesība [Right of superficies]. Jurista Vārds, December 3, No. 49 (800), 2013. Available at: https://juristavards.lv/arhivs.php? $k=v i s s \& d=03 / 12 / 13,03 / 12 / 13 \& h$ fraze $=1$ [last viewed September 2, 2019]; Rozenfelds J. Apbūves tiesibas regulējums Latvijā - grozījumi Civillikumā [Regulation of the Right of Superficies in Latvia]. Jurista Vārds, January 12, No. 2 (905), 2016. Available at: https://juristavards.lv/arhivs.php? $k=v i s s \& d=12 / 01 / 16,12 / 01 / 16 \&$ h_fraze $=1$ \&pageset $=10$ \&page $=3$ [last viewed September 2, 2019].

22 Judgement of the Supreme Court case No. SKC-1800/2012 Available at: http://at.gov.lv/lv/ judikatura/judikaturas-nolemumu-arhivs/civillietu-departaments/hronologiska-seciba?year=2012 [last viewed September 3, 2019]. 


\section{Adverse possession}

Possession apart from property cannot create title. ${ }^{23}$ Still, there is a tendency to defend rights of an emptor who has acquired possession of immovable property, even if this person was hesitant to register the acquired immovable property in the Land Register. Reasons for such procrastination are unclear. The most common explanation is that both parties consider registration to be mere formality; the relatively high stamp duty could also aggravate the problem, as could a delay in payments by the purchaser. The time gap between stepping into the purchase agreement and registration of the acquired immovable property in the Land Register may exceed ten years, which is also the statute of limitation under Latvian law.

In one of the recent cases, ${ }^{24}$ a purchaser who stepped into a purchase agreement dated 24 September 2001, filed a counter-claim over property rights to the purchased immovable property (an apartment in a dwelling house) on August 15, 2016. As the Supreme Court reversed judgment adopted by a court of the lower instances, one cannot learn about the outcome of this case.

However, it is already clear that Latvia is not following the pattern adopted by other countries. Usually, mandatory registration of land in the Land Register excludes any possibility whatsoever to acquire land which is already registered in the name of somebody else (i.e., law precluded so-called usucapio contra tabulas).

This would signal about return to the practice, which was common during the inter-war period, i.e., before introduction of the current CL of 1937, when this issue was governed by its predecessor - the Local Civil Laws (CLL) of 1864. ${ }^{25}$

The time gap between January 28, 1937, when the CL was passed by the Cabinet, and the Soviet occupation, was far too brief to accumulate case law regarding new preconditions for acquisition of immovable property through adverse possession. There are only few publications on the subject, and a single publication addresses this amendment by paying attention to the changes in the wording of the law. ${ }^{26}$ It is worth mentioning that the author of this little-known publication has underlined the significance of the last phrase in Section 1024 of CL as compared to the previous one (Section 855 of CLL). He claimed that by adding this additional

${ }^{23}$ However, case law has not always been in line with this rule, see: Rozenfelds J. Ownership Claim. Journal of the University of Latvia, Law, No. 6, Lazdiňš J. (ed.-in-chief), Riga: University of Latvia, 2014, pp. 91-107; see also: Rozenfelds J. Ownership Acquired in Good Faith. Journal of the University of Latvia, Law, No. 10. J. Lazdinš (ed.-in-chief). Riga: University of Latvia, 2017, pp. 58-74.

${ }^{24}$ Case No. SKC-195/2019. Available at: http://www.at.gov.lv/lv/judikatura/judikaturas-nolemumuarhivs/civillietu-departaments/hronologiska-seciba?year=2019 [last viewed September 2, 2019].

25 Digitalized version of the original of the Civil laws (in Russian) of 1864 (Part III of the Codification of Local Laws). Available at: https://www.lndb.lv/Search/Search?FreeFormQuery=1864\&PageInd ex $=2 \&$ PageSize $=12 \&$ SearchEndpointID $=0 \&$ SearchResultViewMode $=$ List $\& I s C u s t o m V i e w M o d e=$ False\&SortingField=Relevance\&IsStopwordRemovalDisabled=False\&IsDuplicateCollapsingDisab led=False\&SelectedDocumentSets=DOM [last viewed September 2, 2019].

26 Publication of unknown date included in the collection of works by this author: Vinzaräjs N. Ieilguma nozīme civiltiesību sistēmā. Civiltiesību problēmas [Significance of the prescription in the system of civil law]. Kalniņš E. (ed.)., publishers: Erlena Kalniņa un Viktora Tihonova izdevums, Riga, 2000, pp. 83-94. 
phrase, the legislator had aimed at precluding acquisition through adverse possession of immovable property ipso iure. ${ }^{27}$ The abovementioned author also stated that the amendments to the $\mathrm{CL}$ precluded usucaption ${ }^{28}$ of the immovable through prescription, even if the said immovable was registered in the Land Register under the name of another person (so-called usucapio contra tabulas).

However, the court in the case No. SKC-195/2019 has cited the inter-war case without paying attention to the fact that wording of the relevant law has been changed. In doing so, the court can reverse case law, which the legislator tried to avoid back in 1937.

\section{Conclusions}

A simple answer to the question why such structures as a pipeline or Inčukalns underground gas storage, albeit privatized, have never been registered in the Land Register, but are nevertheless regarded as subject of separate ownership, is that they are too big to be ignored. None of the several thousand proprietors has ever bothered to ask whether they would have some piece from the gigantic structure that is spoiling a significant part of their land, as does the abovementioned pipeline, or puts their underground space under certain strain, as does the Inčukalns gas storage. No one has ever doubted property rights of the said "appurtenances" - owners of the soil have never disputed that certain rights belong to another person. This extralegal status of the said constructions makes them unique phenomena of law.

Comparing of the described phenomena with the situations similar in their legal shape but significantly smaller in physical measures, one could find that usually such structures are either dealt with as split property (with compulsory rent as consideration for the use of the land plot in the ownership of the landlord $)^{29}$, real servitude (without any remuneration for the owner of a servient (i.e. property burdened by said servitude), immovable property ${ }^{30}$ or (since 2017) - the right of superficies. This solution resembles regulation of a similar situation by the Swiss Civil law: "Conduits of water, gas, electricity and such like, even where they pass beyond the land for which they have been laid, are, in the absence of a contrary provision, held to be accessory to the works from which they run and to the property of the owner of these works [... Where the conduit is not visible from the outside,

27 Ipso iure [Latin "by the law itself"], i.e. By the operation of the law itself despite the parties' actions the property will revert to another person - Black's Law Dictionary Seventh Edition. Editor in Chief Bryan A.Garner. St. Paul, Minn : West Group, 1999, p. 834.

28 Usucaption - the acquisition of ownership by prescription - Black's Law Dictionary Seventh Edition. Editor in Chief Bryan A.Garner. St. Paul, Minn : West Group, 1999, p. 1542.

29 Judgement of the Riga Regional court of March 5, 2018. No. CA-0504-18/37 (in Latvian) Available at: https://manas.tiesas.lv/eTiesasMvc/nolemumi [last viewed September 3, 2019].

30 Judgement of the Supreme Court of the Republic of Latvia. No. SKC - 304/2006. Available at: http:// at.gov.lv/lv/judikatura/judikaturas-nolemumu-arhivs/civillietu-departaments/hronologiskaseciba?year=2006 [last viewed September 2, 2019]. 
the servitude is constituted by entry in the land register, in other cases by the laying of the conduit itself" (Section 676 of Swiss Civil Code). ${ }^{31}$

Another, quite similar solution could be found in more contemporary Article 20, paragraph 2, Book 5 of the Civil Code of the Netherlands: the ownership of a network consisting of one or more cables or pipelines destined for transporting solid, fluid or gaseous substances, energy or information that is or will be laid on or above land of other persons belongs to the person who rightfully laid such network or their assignee. ${ }^{32}$

It becomes evident that there is no cure fit for all. It seems that pipelines, which are crossing the country and thus serving national interests, must be evaluated by their strategic importance and, if necessary, the land plots, which are physically connected to the said pipelines - nationalised (as their restitution to the previous owners was misplaced ${ }^{33}$ ).

The problem of underground gas storage is different. Use of naturally formed underground caverns for gas storage does not have any practical interference with the interests of the proprietor of the land plot. It is not an interference with the owner of the underground cavern. Their interests are limited by surface of the land plot up to 20 metres under the ground for extraction of subterranean water or minerals (Section 4, Section 11 of Law On Subterranean Depths ${ }^{34}$ ).

The problem does not arise with the underground caverns but instead with regulation of real property rights which are too wide. Latvia is probably the only country in Europe which has imposed unlimited ad caelum ${ }^{35}$ rights upon the owner. Owners of land own not only the surface thereof, but also the airspace above it, as well as the land strata below it and all minerals which are found in it (Section 1042 of CL). This unlimited access to the underground must be redrafted on the model of rights which are applied all around Europe, i.e., the right of the owner of a plot of land extends to the space above the surface and to the subsoil under the surface.

31 Cited from the Swiss Civil Code. English version by Ivy Williams published by Oxford University Press, 1925 reprinted by Remark Verlag Zurich, 1976 completely reset, revised and up-dated edition with Notes, Vocabularies, Index and a Synopsis of all changes of the law since 1912 by Siegfried Wyler, Barbara Wiler, Vol. II, Remak Verlag Zurich.

32 The Civil Code of the Netherlands. Kluwer Law International. Wolters Kluwer. Law \& Business. Hans Warendorf. Richard Thomas. Ian Cury-Summer. 2009 Kluwer Law International BV, the Netherlands.

33 Law On Land Reform in the Cities of the Republic of Latvia. Available at: https://likumi.lv/doc. php?id=70467 (in Latvian); law "On Land Privatisation in Rural Areas". Available at: https:// likumi.lv/doc.php?id=70467 (in Latvian) [last viewed September 2, 2019].

34 Available at: https://likumi.lv/ta/en/en/id/40249-law-on-subterranean-depths [last viewed September 2, 2019].

35 Rozenfelds J. Entropy of Physical Unity of property (ad caelum) in the Latvian Law. International Scientific Conference "The Quality of Legal Acts and its Importance in Contemporary Legal Space". 4-5 October, Riga: University of Latvia, 2012, pp. 615-625. 
However, the owner may not prohibit influences that are exercised at such a height or depth that he has no interest in excluding them. ${ }^{36}$

Considering the ill-advised development of the concept of registration of the littoral zone of the Baltic Sea in the Land Register, it seems apparent that there is a lack of understanding of the concept of public domain in perception of property law in Latvia. a public domain is unalienable. The above mentioned concept on littoral zone of Baltic see reflects directly the opposite view, i.e., as if the state could deal with the littoral zone as it pleases, even as a result of such reckless attitude the littoral zone becomes private property.

There is an urgent need not only to develop but also to amend the current law in order to corroborate the principle that land in the public domain can be subject to particular rules for achievement of public interest purposes and shall be exempt from the transfer. Property that forms a part of the public domain is inalienable and cannot be object of rights in favour of third persons (Section 82,3 Italian Civil Code) ${ }^{37}$

Right of superficies should be applied to the whole range of immovable property wherever there is a need to get rid of divided or split property.

Amendment should be made in the Section 1070 CL establishing rule that the agreement on divided use of a joint property if registered in the Land Register should become binding to the third parties.

\section{BIBLIOGRAPHY}

\section{Literature}

1. Bērziņš G. Apbūves tiesība risinās dalītā īpašuma problēmu [Right of superficies will solve the problem of the divided property]. Jurista Värds, October 3, 2014. Available at: https:// juristavards.lv/zinas/265369-gberzins-bapbuvesb-tiesiba-risinas-dalita-ipasuma-problemu/ [last viewed September 2, 2019].

2. Rozenfelds J. Pētījums par Civillikuma Lietu tiesību dạas (ceturtās, piektās, sestās un septītās nodalas) modernizācijas nepieciešamïbu [Research on necessity of modernization of the fourth, fifth, sixth and seventh subchapter of the Third Chapter of Civil Law]. Available at: https://www.tm.gov.lv/lv/nozares-politika/petijumi [last viewed September 3, 2019].

3. Rozenfelds J. Entropy of Physical Unity of property (ad caelum) in the Latvian Law. International Scientific Conference "The Quality of Legal Acts and its Importance in Contemporary Legal Space”. 4-5 October, Riga: University of Latvia, 2012, pp. 615-625.

36 Section 905 of the German Civil Code, BGB. Available at: http://www.fd.ulisboa.pt/wp-content/ uploads/2014/12/Codigo-Civil-Alemao-BGB-German-Civil-Code-BGB-english-version.pdf [last viewed September 2, 2019].

37 The Italian Civil Code and Complementary Legislation. Translated in 1969 by Mario Beltramo, Giovanni E. Longo, John H. Merryman. Supplemented, translated and edited by Mario Beltramo (from 1970 through 1996). Subsequently supplemented, translated and edited by Susanna Beltramo. Book three. Property Rights. (Articles 810-1172), Booklet 5, Oceana, Release 2007-1 Issued April 2007, p. 3. 
4. Rozenfelds J. Apbūves tiesība [Right of superficies]. Jurista Vārds, December 3, No. 49 (800) 2013. Available at: https://juristavards.lv/arhivs.php?k=viss\&d=03/12/13,03/12/13\&h fraze $=1$ [last viewed September 2, 2019].

5. Rozenfelds J. Ownership Claim. Journal of the University of Latvia. Law. No. 6. Lazdiñs J. (ed.-in-chief), Riga: University of Latvia, 2014, pp. 91-107.

6. Rozenfelds J. Apbūves tiesības regulējums Latvijā - grozījumi Civillikumā [Regulation of the Right of Superficies in Latvia]. Jurista Värds, January 12, No. 2 (905), 2016. Available at: https://juristavards.lv/arhivs.php?k=viss\&d=12/01/16,12/01/16\&h_fraze $=$ 1 \&pageset $=10$ \&page $=3$ [last viewed September 2, 2019].

7. Rozenfelds J. Ownership Acquired in Good Faith. Journal of the University of Latvia. Law. No. 10. Lazdiňš J. (ed.-in-chief), Riga: University of Latvia, 2017, p. 58-74.

8. The Civil Code of the Netherlands. Kluwer Law International. Wolters Kluwer. Law \& Business. Hans Warendorf. Richard Thomas. Ian Cury-Summer. Kluwer Law International BV, The Netherlands, 2009.

9. Vinzarājs N. Ieilguma nozīme civiltiesību sistēmā. Civiltiesību problēmas [Significance of the prescription in the system of civil law]. Kalniņš E. (ed.), publishers: Erlena Kalniņa un Viktora Tihonova izdevums. Riga, 2000, pp. 83-94.

\section{Legislative acts}

1. Amendments to the Civil Law. Official Publications No. 2015/56.5. Available at: https:// www.vestnesis.lv/op/2015/56.5 [last viewed September 3, 2019].

2. Law On Land Reform in the Cities of the Republic of Latvia. Available at: https://likumi. lv/doc.php?id=70467 (in Latvian); law "On Land Privatisation in Rural Areas". Available at: https://likumi.lv/doc.php?id=70467 (in Latvian) [last viewed September 2, 2019].

3. The Civil Code of the Netherlands. Kluwer Law International. Wolters Kluwer. Law \& Business. Hans Warendorf. Richard Thomas. Ian Cury-Summer. Kluwer Law International BV, the Netherlands, 2009.

4. The Italian Civil Code and Complementary Legislation. Translated in 1969 by Mario Beltramo, Giovanni E. Longo, John H. Merryman. Supplemented, translated and edited by Mario Beltramo (from 1970 through 1996). Subsequently supplemented, translated and edited by Susanna Beltramo. Book three. Property Rights. (Articles 810-1172). Release 20071 Issued April 2007. Oceana.

5. Par Koncepciju par Baltijas jūras un Rīgas jūras līča piekrastes joslas ierakstīšanu zemesgrāmatā uz valsts vārda. Ministru kabineta rỉkojums Nr. 241 Rīgā 2008. gada 29. aprīlī (prot. Nr. 27 24.\$) [Regarding Conception on recording of the costal line of the Baltic Sea and the Gulf of Riga in the name of the State. Cabinet Regulation No. 241]. Available at: https://likumi.lv/ta/ id/174726-par-koncepciju-par-baltijas-juras-un-rigas-juras-lica-piekrastes-joslas-ierakstisanuzemesgramata-uz-valsts-varda [last viewed September 4, 2019].

\section{Legal practice}

1. Judgement of the Supreme Court Civil law department in the case No. C12307410; SKC-0268/2016 Available at: https://manas.tiesas.lv/eTiesasMvc/nolemumi [last viewed September 3, 2019]. 